\title{
Internal Control System Weakness and Non-Compliance to the Provision of Legislation in Practicing Audit of Local Government in Indonesia
}

\author{
Erny Prasetyaningsih, Gufratul Yuhalifiyah, Heri Susanto \\ Sebelas Maret University, Surakarta, Indonesia \\ Email: anggrek_po@yahoo.com, Ghufra_rizfuta@yahoo.co.id, Herisusanto303@gmail.com
}

Received 22 July 2014; revised 16 September 2014; accepted 4 October 2014

Copyright (C) 2014 by authors and Scientific Research Publishing Inc.

This work is licensed under the Creative Commons Attribution International License (CC BY). http://creativecommons.org/licenses/by/4.0/

\section{(c) (i) Open Access}

\begin{abstract}
This study developed a statistical model of non-compliance reporting provisions of law and control of the system of internal control findings BPK. BPK is abbreviation for Badan Pemeriksa Keuangan, the Supreme Audit Agency in Republic of Indonesia. The purpose of this study was to analyze the factors that affect the outcome of the Supreme Audit Agency audit opinion received by the local government. This study has selected 371 samples to the local government for the year 2012 . Research uses financial statement data in the form of government in 2012 soft copy of the Supreme Audit Agency and other publications. The results showed that non-compliance reporting provisions of low and system of internal control weakness has significant effect on the administration of the BPK audit opinion.
\end{abstract}

\section{Keywords}

Agency Theory, The System of Internal Control, Compliance on the Implementation and BPK Audit Opinion

\section{Introduction}

UNDP affirms that the principals of good governance consist of participation, obedience of the law, transparent, responsive, oriented agreements, equality, effective and efficient accountability and strategic vision. It is clearly defined that accountability is one important aspect in good governance. Many developed countries in Europe like German, and England have applied the concept of accountability almost in every aspect of governance since 
1970. England in john Major era and Tony Blair promoted the accountability by making Output and Performance Analysis (OPA Guidance) or treasury guidelines to the department or institution in government and Guidence on Annual Report that contain indication of annually report of one institution to the minister, parliament, and public (Feyi, 2012).

Interim examination is preliminary audit that is done before the audit of finance report is done. The interim examination is done before examining to LKPD. LKPD is abbreviation for Laporan Keuangan Pemerintah Daerah (Local Government Financial Statements in Republic of Indonesia). Interim examination is a part of examination to LKPD and also a common practice in the finance report examination. The implementation of interim examination to LKPD is an alternative for the limited time solution of checking by BPK RI to LKPD that is stated in the regulations of law; it is two months after BPK RI accepted LKPD (IAI, 2004). The implementation of regional autonomy is since the regulations No 22 year 1999 was published, it's about the local government that is renewed by the regulation No 32 year 2004, it's about the local government (Law No 32/2004), and the regulations No 25 year 2005. It's about financial balance between central and local areas. According to the regulation No 32 year 2004, regional autonomy is the right authority and obligation of regional autonomy to organizing and taking care of own business in the government and the local social need as the laws and regulation.

By the regional autonomy, there is a change in the financial management as it is proved with three packets of regulations in the financial field of state; it is regulations No 17 year 2003 about state finance, regulations No 1 year 2004 about state treasury, and regulations No 15 year 2004 about management and responsibility of state finance. Those three packets are organizing and managing the state finance to be more democratic and managing to give the sanction for those organizing the state finance. This gives an effect of those that have sanction of local government, by giving an authority to manage finance local government so that it will raise transparency and accountability. For this, the report of finance local government will be audited by BPK RI as the external auditor of regional government in Indonesia (Hapsari et al., 2013).

As the transparency of finance state managers work by local government and audit of the local finance government by BPK, BPK makes report of the audit and Indonesian republic government calls it LHP. LHP is abbreviation for Laporan Hasil Pemeriksaan. LHP contain three phases including finance, internal controlling and obedience. In LHP, BPK gives the outcome of findings with giving recommendation as the improvement of the financial systems, internal controlling or obedience. The numbers of findings or recommendation in LHP are influenced by the implementation of the system in organizing the local finance, internal controlling system and the implementation of the legislation that still exist. The existence of the problem and application of the internal system in the internal controlling and disobedience for the application on the regulation toward giving an opinion of the audit become motivation for the researcher to make more research.

\section{Review of Literature and the Development of a Hypothesis}

\subsection{Agency Theory on Government Organization}

Basically the sector organization is built on the basis of agency theory, it is admitted or not in the government there is a relationship with the agency problem (Abdullah, 2005). According to Lane (2000) basically organization sector can be established on agency theory base. It is admitted or not in the government there is a relationship with the agency problem. He claimed that democratic country based on a series principal agent relationship. The same theory stated by Moe (1984) which explained the concept of economic organization in public sector using agency theory. Bergman and Lane (1990) in Setiawan (2012) stated that the framework of the principal relationship is an approach that very important to analysis the public policy commitment.

Agency relationship in agency theory rises when there is an assignment from the individual (principal) to other individual (agent). Accordance with Jensen \& dan Meckling (1976) the agency problem can arise for each individual can be assumed will have a preference to maximize the personal utility that probably have a contrary with another individual interest. Based on this assumption that probably will get the lost by the agent to apply the assignment for the agent is prefer to choose to maximize personality need.

Referring to the Law No 32 of 2004 participant include the people in the government organization, regents or mayors, and parliament. In the regulations regents and mayors has responsibility for planning, implementation and accountability of government program that act as executive. Mechanism of the regents and mayors election by the people has showed the delegation of an authority from the people to the regents and mayors. This thing showed that regents and mayors acting as the agent and the people as principal within the frame work of the agency relationship. 
In the Law No 32 of 2004 the parliamentary is a partner of regents and mayors that acting as controlling and legislation. Parliament is representation of the people that decision making in formal case for the parliament elected by the people. This shows that council has a function as a channel to accommodate the people interest in decision making by the executive.

Based on agency theory management of local government should be supervised to ensure the management is done with full of compliance to the various rules and regulations. According with Law No 15 of 2004 (Law No $15 / 2004)$ inspection is the process of identify the problem analysis, and evaluation that is carried out independently, objectively, and professional. Based on the standard of inspection, is to assess the correctness, accuracy, credibility, and reliability information on the management and responsibility to the financial state. With increasing accountability of local government received information society becomes more balanced against local government. Where it has meaning asymmetry information those possibilities for corruption also becomes smaller (Setiawan, 2012).

One form of control, in Indonesia is formed by an independent auditing agency to audit the local government in Indonesia. In Indonesia, the oversight is conducted by the supreme audit agency (BPK). According to Law No 15 of 2006 (Law 15/2006) the Supreme Audit Agency, hereinafter abbreviated as BPK, is a state agency whose job is to examine the management and financial responsibility of the state. The examination is conducted by the supreme audit agency (BPK) consist of audit, inspection and examination performance with specific purpose. The result of the tests that is carried out by the supreme audit agency (BPK) is an opinion, findings, conclusions, or the form of recommendations.

\subsection{Internal Control System (SPI)}

Internal control of the central government and local government is designed based on the government regulation No 60 of 2008 regarding the government internal control system and Indonesian republic government called it SPIP. SPIP is abbreviation for Sistem Pengendalian Intern Pemerintah. The government regulations state that SPI is an integral process to the action and activities that is carried out continuously by the chief and all employers to ensure for the success that is achieved the purpose of organization through the effective activities and efficient, the reliability of financial reporting, safeguarding of state asset, and compliance with laws and regulation while the government internal control system (SPIP) in the PP No 60 of 2008 is internal control system for whole in the central government and local government.

The government regulation (PP) No 8 of 2006 about the financial reporting and the performance of government agency, states that SPI is a process is influenced by management that is created to prove sufficient confident in achieving effectiveness, efficiency, and obey to the regulations and reliability of the financial statement of the government.

The government regulation or (PP) No 60 of 2008 on government internal control system (SPIP) which is adopted from The Committee of Sponsoring Organizations of the Treadway Commissions (COSO) Internal Control Framework with adjustment made according to needs and characteristic of Indonesian government. SPIP is integrated and continuous process done by the government agency, and has dynamic character and always up to date.

\subsection{Disloyalty to the Laws Provision}

As a part of the acquisition of reasonable assurance whether the financial statement are free from material misstatement, according to the state auditing standard, and Indonesian republic government called it SPKN. SPKN is abbreviation of Standard Pemeriksaan Keuangan Negara, BPK performs an obedient test on local government to entity the rules and regulations, fraud and impropriety that has direct influence to present the finance report. Audit that is performed by BPK on the financial statement of local government entity that is not a specific designed to state opinion for the obedience to overall provisions and legislation. Therefore, BPK does not state an opinion like that. For non-compliance with statutory provisions may result the loss of area, areas of potential loss, lack of receptions, administration, inefficiency and ineffectiveness.

The compliance of the audit (compliance audit) in the government is an important thing that also needs to be concerned in addition to internal control (internal control). According to Arens (2005: 14) the compliance of the audit is carried out to certain is the auditee has followed specific procedure, etiquette, and regulations that has stated by higher authority. According to the state auditing standard that issued by BPK RI (The Supreme Audit 
Agency in Republic of Indonesia), the auditor must prepare a report on the results of the compliance check that state of non-compliance with the provisions to the laws and regulation, Including stating of disclosure of administrative irregularities, violation of civil engagement, deviations that contains of elements of crime, and a significant of non-compliance.

\subsection{BPK Audit Findings}

Audit is the process in systematic examination conducted to know how the implementation is really set (Pramono, 2007). According to hall (2007) auditing is a form of independent verification that is conducted by expert-auditor that expresses the opinion the fairness of the financial statements of the company. The confident of the public in the reliability of the financial statement that is resulted internally depends on the validation directly by independent expert-auditor.

Law No 15 of 2004 (Law No 15/2004) on the audit of financial management and accountability of state finance stated that the examination is the process of problem identification, analysis, and evaluation that is carried out independently, objective and professional based on the examination standard, to assess the correctness, accuracy, credibility, and reliability of the information on the management and responsibility to the state finance. The inspection of state finance is conducted by the supreme audit agency (BPK), and consists of finance audit, performance audit and with the particular purpose. The results that is conducted by the supreme audit agency (BPK) is an opinion, findings, conclusion, or in the form of recommendation.

The results that is conducted by the supreme audit agency (BPK) is an opinion, findings, conclusion, or in the form of recommendation. The audit findings by BPK are cases that found to the local government financial report for the violation that is conducted of local government in the internal control provision or the provision of the applicable legislation.

\subsection{The Consideration of Auditor Opinion}

The auditor report is a media which is used to communicate with its environment. Opinion of the audit which is given by auditor with many steps of the audit until the auditor can give conclusion on the opinion that must be given for the finance audited. Arens et al. (2003: 36) argues that the audit report is the final step of the entire audit process. Thus the auditor in giving opinions has been based on the professionalism beliefs.

Based on the Law of RI No 15 of 2004 on the examination and management and financial state responsibility stated that the definition of opinion is a professional statement as the conclusion of the auditor on the level of fairness of the information that is presented in the financial statement.

The supreme audit agency (BPK) of RI (2010) explained that opinion is professional statement as the conclusion of auditing on the level of fairness of the information that is presented in the financial statement that is based on the:

1) Conformity with the government accounting standard.

2) Sufficiency of disclosure.

3) Obedience to the legislation.

4) Effectiveness of internal control system (SPI).

\subsection{The Frame of Mind}

The theoretical of frame mind is that described the effect of the independence variable to the dependent variable they are on the weakness of system of intern control and non-compliance for the provision of legislation on the consideration opinion audit in supreme audit agency (BPK) as below (Picture 1):

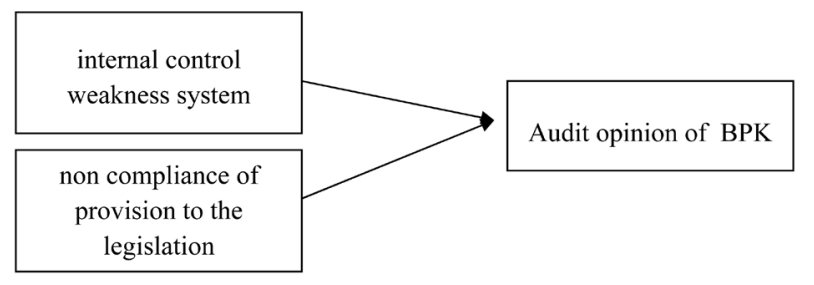

Picture 1. Effect of the independence variable to the dependent variable. 


\subsection{Hypothesis}

H1: the system of internal control weakness affects to the consideration of giving opinion audit in supreme audit agency (BPK).

H2: non-compliance to the provision of laws affects to the consideration of giving opinion audit in supreme audit agency (BPK).

\section{Research Method}

\subsection{Population and Sampling}

Population in the research is the local government in city or regent in Indonesia of 2012. The sampling technique that using purposive sampling with sampling criteria is in the city/regency in Indonesia year 2012, the local government/regency that published the local government financial report had been completely in year 2012 and had been audited by BPK of RI, that is required in the measurement of variable and analysis data to have hypothesis test research. In this research there are 415 local governments/regency year in 2012, and who meet the criteria above so that it can be sampled are 371 local governments.

\subsection{Data and Sources of Data}

The source of data in this research is secondary data (secondary data). Secondary data is data that has been exist and available so it is no need to be collected by researchers (Sekaran \& Bougie, 2013) in the secondary data is a softcopy of the report from the results examination on the financial local government report/regency by supreme audit agency (BPK RI) in Indonesia.

\subsection{Variables Research and Measurement of Variables}

This study using independent variables, namely:

1) The system of internal control weakness as measured from the number of cases of weakness in the system in accounting and reporting control, flaws revenue and expenditure budget control, the weakness of internal structure control.

2) Non-compliance to the laws that been measured from the loss of local government totally, the loss of potential areas, lack of reception, administration, inefficiency and effectiveness.

Dependent variable that is used is measured with dummy variable 1 is to get the fairness with no exception (WTP), 0 is to other fairness opinion with no exception.

\section{Method of Data Analysis}

\subsection{Testing Hypothesis}

In this study, testing is done by multiple linear regression analysis; it is a statistic method that often used to research the relationship between dependent variables and independent variables.

For the regression model that is used as follows:

$$
\mathrm{OAB}=\beta_{0}+\beta_{1} \mathrm{KSPI}+\beta_{2} \mathrm{KKP}+\varepsilon
$$

Explanation:

$\mathrm{OAB}=$ audit opinion of BPK.

KSPI $=$ internal control weakness system.

$\mathrm{KKP}=$ non-compliance of provision to the legislation.

$\varepsilon=$ error.

$\beta_{0}=$ konstanta.

$\beta_{1}=$ regression coefficient weakness of internal system control.

$\beta_{2}=$ regression coefficient of non-compliance to the legislation.

\subsection{Appropriateness Estimated Model}

Appropriateness estimated model (Goodness of Fit) is often called determination coefficient (R2) that has purpose to measure the ability of the model to explain the dependent variables. The coefficient determination results 
are between zero (0) and one (1). Small value of R2 means the ability of independent variables in explaining the variations of dependents variables that is very limited. The value that close to one means independents variables that provide almost the information needed to predict the dependents variables. If there is a negative adjusted R2 value, the adjusted R2 values are considered equal to zero (0).

\subsection{Decision Making}

The decision is based on the probability (p)/coefficient and significance $\mathrm{t}_{\text {-test }}$ :

Hypothesis 1 decisions are taken based on the probability (p)/koefisien signifikansi $t_{\text {-test }}$ KSPI:

If (p) $\mathrm{t}_{\text {-test }}$ KSPI $>0.05$, $\mathrm{H} 1$ rejected.

If (p) $\mathrm{t}_{\text {-test }}$ KSPI $<0.05$, H1 accepted.

Hypothesis 2 decisions are taken based on the probability (p)/koefisien signifikansi $t_{- \text {test }}$ KKP:

If (p) $\mathrm{t}_{\text {-test }} \mathrm{KKP}>0.05, \mathrm{H} 1$ rejected.

If (p) $\mathrm{t}_{\text {-test }} \mathrm{KKP}<0.05$, H1 accepted.

\section{Research Result and Discussion}

Based on existing research data it can be obtained the results of descriptive statistic as follows (Table 1):

Descriptive statistic of this research indicate that the variable weakness has internal control system has minimum value of 0 , it is in the local government in Banjar, it shows that the internal control system in Banjar City can be said a perfect there is no weakness and the maximum value is 38 it exist in the province north Sulawesi. Average of 10.39 and a standard deviation of 4.984 standard value, the deviation that smaller from average value indicates that the variable value of weakness intern control system among the local government in Indonesia is not much different. While the average of non-compliance provisions of legislation is 13.94 it means the average sample of local government experiencing the problem that violates the laws.

Variable of adherence to the provisions of law has minimum value 1 it exist in Sambas Regency and the maximum value is 90 that exist in the province of north Sulawesi, average 13.49 and non-compliance provisions of legislation is has minimum value 1 that exist in Sambas regency and maximum value is 90 that exist in the province of north Sulawesi, average 13.49 and a standard deviation 8.743, The deviation standard value that smaller from average value indicates that the value of different variable of non-compliance with the provision of laws in the each small local government.

Variables audit opinion of BPK has minimum value of 0 , according to the government data on the number of value 0 there are 360, and maximum value of 1 there is 65 . Average 0.18 and deviation standard of 0.38 . It pointed that the local government in Indonesia are still many problems for finance statement.

\subsection{Classical Assumption Test Result}

The classical assumption test is used to know whether the regression model of this research has fulfill classical assumption to ensure whether interpretation got from data analysis does not deviated from significant problem.

In the classical assumption test used multicolinearrity test. The result shows that the model of this research has fulfill classical assumption criteria and there is no significant problem.

\begin{tabular}{lcc|}
\multicolumn{2}{l}{ Result of multicolinearrity test. } & \\
\hline Variable & Tolerance & VIF \\
\hline KSPI & 0.807 & 1.239 \\
KKP & 0.807 & 1.239 \\
\hline
\end{tabular}

Note: Source: secondary data processing.

Table 1. Statistics descriptive research variable.

\begin{tabular}{cccccc}
\hline Variable & N & Mean & SD & Min & Max \\
\hline KSPI & 371 & 10.39 & 4.984 & 0 & 38 \\
KKP & 371 & 13.94 & 8.7431 & & 90 \\
OAB & 371 & 0.18 & 0.381 & 0 & 1 \\
\hline
\end{tabular}

Note: Source: secondary data processing. 
Based on the above table showed that the VIF values of all independent variables are under 10 and to lerance values of all variable as are above 0.1 . This shows that there is no multicollinearity in our model, or no significant correlation between each independent variable. Therefore, the implementation of the testing can be done.

\subsection{Results of Testing the Goodness of Fit Model Research}

The model equation that is used in this study is a linear. It can be proved by looking at the value of Sig in the test result of F (attached) in ANOVAb table. Sig value that is generated is 0.000 , is smaller than alpha 0.05 .

The next analysis is determined the contribution of independent variables on the dependent variable. This can be done by looking at Adjusted R2 in table Summary. From the table it can be showed that value of Adjusted R2 pointed to number 0.067 . This means the intern control system weakness, the weakness of the provisions of the legislation that can explain the dependent variable of audit opinion in BPK by $6.7 \%$ while the remain is $93.3 \%$ for it is influenced by other variables that is not explained in this research model.

\subsection{The Result of Hypothesis Testing}

Testing has influenced the internal control system weakness and non-compliance with laws towards audit opinion in BPK.

Regression equation that is obtained was below (Table 2):

$$
\mathrm{AOB}=0.392-0.011 \mathrm{KSPI}-0.008 \mathrm{KKP}+\varepsilon
$$

\subsection{Testing Has Influenced the Internal Control System Weakness and Non-Compliance with Laws against to Audit Opinion in BPK}

From data above, it obtained t count the weakness variable of internal control system is -2.508 . Based on significantly from -test KSPI for the weakness variable of internal control system is 0.013 at significance level of 5\% until $0.013<0.05$ then $\mathrm{H} 1$ is accepted or it can be said as the weakness of internal control system against the Audit opinion in BPK.

\subsection{Testing Has Influenced to the Non-Compliance with Laws against the Audit Opinion in BPK}

From these data, it obtained t count for the variable of non-compliance to the provision to the laws of -3.123 . Based on significantly from -test $_{\mathrm{KKP}}$ is for non-compliance to the laws variable is 0.002 on the significantly level $5 \%$ until $0.002<0.05$ then $\mathrm{H} 2$ accepted or it can be said that non-compliance of the laws has a significant effect against regarding of Audit opinion in BPK.

\section{Conclusion}

Based on the data that has been done regarding audit opinion in BPK as empirical studies in local government in Indonesia, it can be concluded that the weakness of internal control system and non-compliance to the provisions of laws has significantly impacted audit opinion in BPK.

Because this study found the impact between independent variable and dependent variable, implication for the auditors should plan the field work as the procedure has been stated in Professional standards of public accountants. Republic of Indonesia says it SPAP. SPAP is abbreviation for Standar Profesional Akuntan Publik.

Table 2. Result regression analysis.

\begin{tabular}{ccccc}
\hline Variabel & Std Koef. & Stdized Error & Nilai Koef. & S \\
Konstanta & 0.392 & 0.046 & 8.440 & 0.000 \\
KSPI & -0.011 & 0.004 & -0.140 & -2.508 \\
KKP & -0.008 & 0.002 & -0.175 & 3.123 \\
\hline
\end{tabular}

Note: Source: secondary data processing. 
It is necessary to maintain and increase the credibility and reliability of auditors assessment in society.

This research is also contributed to all local government to increase his performance for the shape of internal control which is shapes of internal control system weakness and non-compliance to the provisions to the laws that can be made as consideration regarding audit opinion by BPK.

This research was conducted with a variety of limitations that may affect the result of the research. This study is only using one year period for sampling in 2012. The next researcher can add variable and sampling so that the results can be generalized.

\section{References}

Abdullah, A. H. S. (2012). Hubungan dan Masalah Keagenan Di pemerintah Daerah (Sebuah Peluang Penelitian Anggaran dan Akuntansi).

Abdullah, S. H. A. (2005). Pengaruh Dana Alokasi Umum (DAU) dan Pendapatan Asli Daerah (PAD) terhadap Belanja Pemerintah Daerah: Studi Kasus Kabupaten/Kota di Jawa dan Bali. Proceeding Simposium Nasional Akuntansi VI, Surabaya, 16-17 Oktober 2003, 1140.

Arens, A. A., Elder, R. J., \& Beasley, M. S. (2003). Auditing dan Pelayanan Verfikasi. Jakarta: PT Indeks.

Feyi, A. S. (2012). Evaluation of Financial Accountability in the Public Sector: A Necessary Concept For Good Governance. Global Conference on Business \& Finance Proceedings, 7.1, 698-710.

Hapsari, S. I. et al. (2013). Penentu Jumlah Temuan BPK atas Sistem Pengendalian Intern dan Kepatuhan (Internal Control Compliance Comments) Pemerintah Daerah di Indonesia. Simposium Nasional Akuntansi XVI, Manado, 25-28 September 2013.

Ikatan Akuntan Indonesia (IAI) (2004). Standar Profesional Akuntan Publik. Jakarta: Salemba Empat.

Jensen, M., \& dan Meckling, W. (1976). Theory of the Firm: Managerial Behavior, Agency Cost and Ownership Structure. Journal of Financial Economics, 3, 305-360. http://dx.doi.org/10.1016/0304-405X(76)90026-X

Lane, J.-E. (2000). The Public Sector-Concepts, Models and Approaches. London: SAGE Publications.

Moe, M. T. (1984). The New Economics of Organization. American Journal of Political Science, 28, 739-777. http://dx.doi.org/10.2307/2110997

Peraturan Pemerintah (PP) Nomor 60 Tahun 2008 tentang Sistem Pengendalian Intern Pemerintah (SPIP).

Peraturan Pemerintah (PP) Nomor 8 Tahun 2006 tentang pelaporan keuangan dan kinerja instansi pemerintah.

Pramono, R. (2007) Pengaruh Profesionalisme Auditor Terhadap Pertimbangan Tingkat Materialitas dan Proses Pengauditan Laporan Keuangan. Skripsi UNNES (Diakses 1 Mei 2012). www.google.com

Republik Indonesia (2004). Undang-Undang Nomor 15, Tahun 2004 tentang Pemeriksaan Pengelolaan dan Tanggung JawabKeuangan Negara. Jakarta.

Republik Indonesia (2004). Undang-Undang Nomor 32, Tahun 2004 tentang Pemerintahan Daerah. Jakarta.

Republik Indonesia (2006). Undang-Undang Nomor 15, Tahun 2006 tentang Badan Pemeriksa Keuangan. Jakarta.

Sekaran, U., \& Bougie, R. (2013). Research Methods for Business. United Kingdom: John Wiley \& Sons Ltd.

Setiawan, W. (2012). Pengaruh Akuntabilitas Laporan Keuangan Pemerintah Daerah (LKPD) Terhadap Tingkat Korupsi Pemerintah Daerah Di Indonesia, Skripsi Program Sarjana Fakultas Ekonomi Universitas Diponegoro Semarang. 
Scientific Research Publishing (SCIRP) is one of the largest Open Access journal publishers. It is currently publishing more than 200 open access, online, peer-reviewed journals covering a wide range of academic disciplines. SCIRP serves the worldwide academic communities and contributes to the progress and application of science with its publication.

Other selected journals from SCIRP are listed as below. Submit your manuscript to us via either submit@scirp.org or Online Submission Portal.
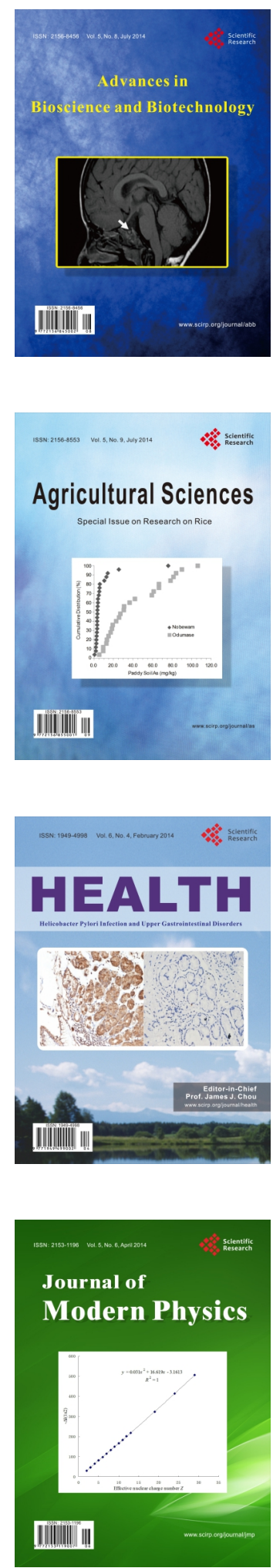
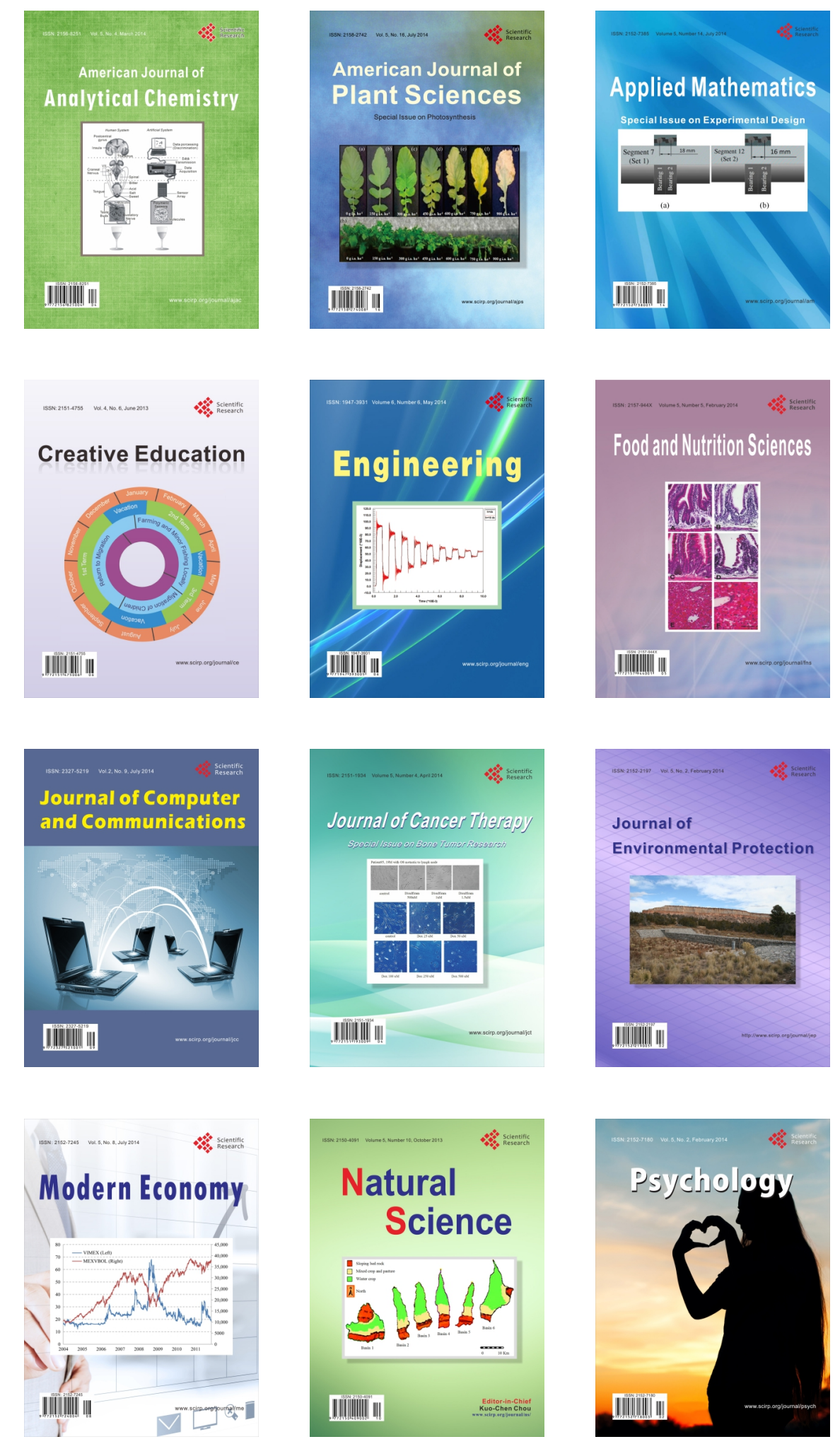